EESTI NSV TEADUSTE AKADEEMIA TOIMETISED. KEEMIA

ИЗВЕСТИЯ АКАДЕМИИ НАУК ЭСТОНСКОИ ССР. ХИМИЯ

PROCEEDINGS OF THE ACADEMY OF SCIENCES OF THE ESTONIAN SSR. CHEMISTRY

$1987,36,3$

УДК 631.811 .98

A. КУУСК, Р. ВЕСКИ

\title{
ПОВЕРХНОСТНАЯ АКТИВНОСТЬ СЛАНЦЕВОГО РОСТОВОГО ВЕЩЕСТВА
}

A. KUUSK, R. VESKI. POLEVKIVI-TAIMEKASVUSTIMULAATORI PINDAKTIIVSUS

A. KUUSK, R. VESKI. SURFACE ACTIVITY OF OIL SHALE-BASED PLANT GROWTH ACTIVATOR

(Представил А. Аарна)

Сланцевое ростовое вещество (СРВ) получают окислительной деструкцией органического вещества сланца-кукерсита азотной кислотой. Оно повышает урожайность и качество многих сельскохозяйственных культур [1, 2]. СРВ представляет собой смесь калиевых солей полифункциональных алифатико-алициклических карбоновых кислот с брутто формулой $\mathrm{C}_{53} \mathrm{H}_{75} \mathrm{O}_{21} \mathrm{~N}_{3} \mathrm{~K}_{4}\left[{ }^{3}\right]$ и, кроме того, содержит неорганические примеси. Средняя молекулярная масса СРВ - 1000-1100. Препарат применяется в виде $0,0001-0,1 \%$-ных водных растворов с рН около 7.

Поверхностную активность СРВ измеряли методом отрыва кольца (метод Дю Нуи) [ $\left.{ }^{4}\right]$ в дистиллированной и жесткой водах (таблица). Воду жесткостью 4,7 мг-экв/л получали растворением 81,5 мг/л $\mathrm{CaCl}_{2}$ и 394,3 мг/л $\mathrm{MgSO}_{4} \cdot 7 \mathrm{H}_{2} \mathrm{O}$ в дистиллированной воде.

Исследуемый 51,7\%-ный водный раствор СРВ (К-соль) при разбавлении в дистиллированной воде до $1 \%$ и ниже становился прозрачным пенящимся. При концентрациях ниже $0,01 \%$ пенообразование практически прекращалось.

\section{Параметры изотерм поверхностного натяжения сланцевого ростового вещества в дистиллированной и жесткой $(4,7$ мг-экв/л) водах при температуре $21^{\circ} \mathrm{C}$}

\begin{tabular}{c|c|c|c}
\hline \multicolumn{2}{c|}{ Дистиллированная вода } & \multicolumn{2}{|c}{ Жесткая вода } \\
\cline { 1 - 2 } $\begin{array}{c}\text { концентрация } \\
\text { СРВ, \% }\end{array}$ & $\begin{array}{c}\text { поверхностное } \\
\text { натяжение, мН/м }\end{array}$ & $\begin{array}{c}\text { концентрация } \\
\text { СРВ, } \%\end{array}$ & $\begin{array}{c}\text { поверхностное } \\
\text { натяжение, мН/м }\end{array}$ \\
\hline 0 & 72,90 & 0 & 72,90 \\
0,002 & 70,60 & 0,0010 & 62,40 \\
0,004 & 66,90 & 0,0025 & 57,60 \\
0,010 & 62,10 & 0,0050 & 54,00 \\
0,020 & 59,40 & 0,0100 & 47,60 \\
0,025 & 58,60 & 0,0250 & 45,90 \\
0,050 & 55,40 & 0,0500 & 44,80 \\
0,100 & 49,20 & 0,1000 & 44,60 \\
0,200 & 46,50 & 0,2000 & 43,60 \\
0,400 & 44,60 & 0,4000 & \\
0,800 & 42,60 & & \\
2,500 & 40,50 & &
\end{tabular}


Методом пересечения прямых в координатах «поверхностное натяжѐние - $\lg$ концентрации» вычисляли величины критических концентращий мицеллообразования (KKM). В дистиллированной воде эта величина составляет $0,251 \%$, в жесткой воде $-0,0275 \%$.

Поверхностная активность СРВ может играть определенную роль в его высокой биологической активности. Проверка этой гипотезы может быть осуществлена разделением СРВ на отдельные фракции и изучением их поверхностной и биологической активности.

\section{Вывод}

Найдено, что по поверхностной активности СРВ сравнимо с известными поверхностно-активными веществами, например с лаурилсульфатом натрия, величина $\mathrm{KKM}$ которого в дистиллированной воде при $20^{\circ} \mathrm{C}$ составляет $0,25 \%$, а минимальное поверхностное натяжение при $30^{\circ} \mathrm{C}-$ $37-38 \mathrm{мH} / \mathrm{м}\left[{ }^{5}\right]$.

\section{Л И Т Е Р А Т У Р А}

1. Вески P., Фомина А. Сланцевое ростовое вещество. Таллин, 1984.

2. Fomina, A. S., Pobul, L. Y., Degtereva, Z. A., Veski, R. E., Kirret, O. G., Nicopensius, I. A., Myannik, A. O., Pyarn, A. V., Poom, A. I., Murumets, K. V., Ulanen, Y. S., Tyanav, I. V., Kotov, A. M. Method for processing of caustobiolites of sapropelite type with oxidizer. Australian Pat. 476436, 1977.

3. Фомина A., Вески P., Мянник A. Химическая переработка сланца-кукерсита на диметиловые эфиры дикарбоновых кислот и сланцевое ростовое вещество. Таллин, 1984.

4. Поверхностные явления и поверхностно-активные вещества. Справочник. Л., 1984, 167.

5. Поверхностно-активные вещества. Справочник. Л., 1979, 30.
Институт химии
Академии наук Эстонской ССР Поступила в редакцию
2/XII 1986 